\title{
CYCLODIALYSIS AB EXTERNO WITH IMPLANTATION OF A COLLAGEN IMPLANT IN SURGICAL MANAGEMENT OF GLAUCOMA
}

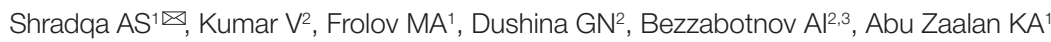

1 People's Friendship University of Russia, Moscow, Russia

${ }^{2}$ Eye microsurgery center «Pro zrenie», Moscow province, Russia

${ }^{3}$ Ophthalmic unit of Skhodnya City Hospital, Khimki, Moscow province, Russia

Glaucoma is one of the main causes of irreversible blindness in the Russian Federation and it is the leading cause of visual impairments among working age population. The primary goal of glaucoma therapy is to preserve the visual function, which is mainly achieved through persistent normalization of IOP by instillation of hypotensive drugs, laser therapy and/or surgery/ In this clinical study safety and efficacy of a glaucoma surgical technique implying valve cyclodialysis ab externo with implantation of a non-absorbable collagen implant (NACl) (Xenoplast, Dubna-Biofarm, Russia) in the supraciliary space were evaluated. All patients exhibited moderate and severe primary open-angle glaucoma (POAG). The efficacy assessment criterias were intraocular pressure (IOP) dynamics, use of hypotensive medications, need for repeat surgical intervention and complications. A total of 26 patients (26 eyes) were operated upon and under observation. Twelve months after surgery, 34\% IOP decrease from the baseline level was observed: from $29.5 \pm 6.8$ to $18.8 \pm 4.3 \mathrm{mmHg}$. The amount of hypotensive medications used reduced from $2.8 \pm 0.9$ to $0.6 \pm 0.9$. Applying the criteria recommended by the World Glaucoma Association, complete success was registered in $73.1 \%$ of patients and partial success - in $26.9 \%$ patients. No surgery ended in a failure through the follow-up period. Post-operatively, one patient developed hyphema, 2 patients had some blood elements in aqueous humor and 1 patient had shallow anterior chamber (AC). The suggested surgical technique proved to be an efficient and safe way to decrease IOP and reduce the number of hypotensive medications and had a minimal number of complications associated with the surgery, therefore it can be recommended as a method of choice in patients with advanced stage POAG.

Keywords: glaucoma, glaucoma surgery, intraocular pressure, cyclodialysis ab externo, uveoscleral outflow

Author contribution: Shradqa AS - study concept and design, data collection and processing, statistical processing, article authoring, design of graphs and drawings; Kumar V — study concept and design, data collection and processing, statistical processing, article authoring and editing, overall responsibility; Frolov MA editing and overall responsibility; Dushina GN — study concept and design, data collection and processing, article editing; Bezzabotnov Al — study concept and design; data collection and processing; Abu Zaalan KA — data collection and processing.

Compliance with ethical standards: the study was approved by the Peoples' Friendship University of Russia Medical University Ethics Committee (protocol №16 of November 17, 2016); the patients gave informed consent to participate in the study.

$\triangle$ Correspondence should be addressed: Ahmad S. Shradqa proezd Shokalskogo, 13, bl. 1, Moscow, 127221; sh1988moscow@gmail.com

Received: 16.08.2019 Accepted: 08.10.2019 Published online: 23.10.2019

DOI: 10.24075/brsmu.2019.068

\section{ЦИКЛОДИАЛИЗ АВ ЕХТЕRNО С ИМПЛАНТАЦИЕЙ КОЛЛАГЕНОВОГО ДРЕНАЖА В ХИРУРГИЧЕСКОМ ЛЕЧЕНИИ ГЛАУКОМЫ}

\author{
А. С. Шрадка ${ }^{1 凶}$, В. Кумар², М. А. Фролов ${ }^{1}$, Г. Н. Душина², А. И. Беззаботнов 2,3 , К. А. Абу Заалан
}

1 Российский университет дружбы народов, Москва, Россия

2 ООО Центр микрохирургии глаза «Про зрение», Химки, Московская область, Россия

з Офтальмологическое отделение ГБУз МО «Сходненская городская больница», Химки, Московская область, Россия

\begin{abstract}
Глаукома является актуальнейшей проблемой офтальмологии. Будучи одной из главных причин необратимой слепоты на территории Российской Федерации, она занимает лидирующее место в нозологической структуре инвалидности по зрению среди трудоспособного населения. Хирургическое вмешательтво зачастую является единственным методом лечения рефрактерной глаукомы. Целью данного исследования было оценить безопасность и эффективность гипотензивной операции (ГО) клапанного циклодиализа ab externo с имплантацией в супрацилиарное пространство нерассасывающегося коллагенового дренажа (НКД) у пациентов с продвинутыми стадиями развития первичной открытоугольной глаукомы (ПОУГ). Критериями оценки безопасности и эффективности были: динамика внутриглазного давления (ВГД), количество используемых гипотензивных средств, потребность в повторном хирургическом вмешательстве и наличие осложнений. В результате наблюдения за 26 пациентами (26 глаз) с продвинутыми стадиями ПОУГ через 12 месяцев после оперативного вмешательства было зарегистрировано снижение ВГД на 34\% от исходного уровня (с 29,5 \pm 6,8 до 18,8 \pm 4,3 мм рт. ст.). Количество используемых гипотензивных средств сократилось с 2,8 \pm 0,9 до 0,6 \pm 0,9. Успешность проведенной ГО оценивали согласно рекомендациям Всемирной глаукомной ассоциации: полный успех был достигнут в 73,1\% случаев, а признанный - в 26,9\% случаев. Неудачных исходов от оперативного лечения не наблюдали. Предложенное хирургическое лечение показало высокую эффективность и безопасность снижения ВГД, сокращение числа используемых гипотензивных средств и минимальное количество осложнений у пациентов с продвинутыми стадиями пОУг. Таким образом, метод клапанного циклодиализа ab externo с имплантацией в супрацилиарное пространство НКД можно рекомендовать в качестве терапии пациентов с ПоУГ в связи с его высокой эффективностью и безопасностью.
\end{abstract}

Ключевые слова: глаукома, хирургическое лечение, внутриглазное давление, циклодиализ аb ехtеrnо, увеасклеральный отток внутриглазной жидкости Информация о вкладе авторов: А. С. Шрадка - концепция и дизайн исследования, сбор и обработка материала, статистическая обработка, написание текста статьи, оформление графиков и рисунков; В. Кумар - концепция и дизайн исследования, сбор и обработка материала, статистическая обработка, написание и редактирование текста статьи; М. А. Фролов - концепция и дизайн исследования, редактирования; Г. Н. Душина - концепция и дизайн исследования; сбор и обработка материала, редактирование текста статьи; А. И. Беззаботнов - концепция и дизайн исследования, сбор и обработка материала; К. А. Абу Заалан - сбор и обработка материала.

Соблюдение этических стандартов: исследование одобрено этическим комитетом медицинского института Российского университета дружбы народов, (протокол № 16 от 17 ноября 2016 г.); все пациенты подписали добровольное информированное согласие на участие в исследовании.

$\triangle$ Для корреспонденции: Ахмад Салех Солиман Шрадка

проезд Шокальского, д. 13, корп. 1, г. Москва, 127221; sh1988moscow@gmail.com

Статья получена: 16.08.2019 Статья принята к печати: 08.10.2019 Опубликована онлайн: 23.10.2019

DOI: 10.24075/vrgmu.2019.068 
Glaucoma is one of the main causes of irreversible blindness in the Russian Federation and it is the leading cause of visual impairment among working age population. [1,2]. In 2013, there were 1,180,708 patients registered with this diagnosis in Russian Federation. According to the World Health Organization, there are 60.5 to 105 million people worldwide suffering from glaucoma. The disease turns blind 1 adult person every minute and 1 child every 10 minutes [1].

Glaucoma is a multifactorial disease. Today, there is no consensus as to its etiology and pathogenesis. The primary goal of glaucoma therapy is to preserve the visual function, which is mainly achieved through persistent normalization of IOP by instillation of hypotensive drugs, laser therapy and/ or surgery $[3,4]$. Some researchers report that in 62 to $82 \%$ of patients' glaucoma is at its advanced stages when it is diagnosed for the first time; in such cases local instillation of hypotensive medications are effective only for a short term [5].

Activation of the aqueous humor outflow through natural pathway is probably the most promising surgery aimed to treat POAG [6-9]. These paths are trabecular and uveoscleral outflow pathways (UOP). From the point of view of surgery, UP boasts great potential because of its anatomical and physiological features. Some ophthalmologists believe that there is a link between the uveoscleral outflow path and the eyeball and orbit's lymphatic system [10]. Current glaucoma surgical techniques aimed at activating the UOP imply cyclodialysis with implantation of various types of drainage devices in the supraciliary space. In Russia, the most common implants selected for such surgeries are auto sclera strips [9]. In other countries, surgeons opt for CyPass MicroStent (Transcend Medical; USA), iStent Supra (Glaukos; USA), Gold Shunt (SOLX; USA), STARFlo (iSTAR Medical; Belgium), and Aquashunt (OPKO Health Inc.; USA) [11-13].

A surgical UOP activation technique implying cyclodialysis ab externo with implantation of $\mathrm{NACl}$ in the supraciliary and suprachoroidal spaces has been developed. The implant is usually used to prolong the hypotensive effect after nonpenetrating deep sclerectomy.

Purpose. To evaluate the effectiveness and safety of a novice glaucoma surgical technique implying valve cyclodialysis ab externo with implantation of $\mathrm{NACl}$ supraciliary space in moderate and severe POAG patients.

\section{METHODS}

A total of 26 patients (26 eyes) aged 54 to 87 years (mean age $73.0 \pm 8.3 ; 12$ male and 14 female), exhibiting severe POAG were operated upon and under observation. Seventeen patients (65.4\%) exhibited severe POAG and 9 (34.6\%) - terminal stage of glaucoma.

The inclusion criteria were: POAG; concomitant pathology (POAG and cataract); medically uncontrolled IOP informed consent to participate in the study. The exclusion criteria were narrow-angle glaucoma, secondary glaucoma, patients exhibiting acute attack of glaucoma, and congenital glaucoma. Neither previous cataract surgery nor previous glaucoma surgery substantiated exclusion of participants from the study. The post-surgery follow-up period was 12 months.

Eighteen patients (69.2\%) had undergone simultaneous surgery for concomitant pathology. Thirteen patients (50\%) were suffering from pseudoexfoliation syndrome. Eleven (42.3\%) patients had previously undergone glaucoma surgery. The mean number of previous surgeries associated with glaucoma was 1.6.

Before surgery, all glaucoma patients were instilling one or a combination of two or more hypotensive drugs. Two
(7.7\%) patients were instilling 1 drug, 5 (19.2\%) patients - a combination of 2 hypotensive drugs, 15 (57.7\%) patients 3 drugs and 4 (15.4\%) patients - a combination of 4 drugs. Despite the local hypotensive therapy, the average IOP level before surgery was $29.5 \pm 6.8 \mathrm{mmHg}$.

All patients underwent the following standard ophthalmological examination before surgery: visual acuity checkup, tonometry (used Maklakov method with $10.0 \mathrm{~g}$ ), biomicroscopy, ophthalmoscopy, gonioscopy, ultrasound biomicroscopy (UBM), B-scanning and optical coherence tomography $(\mathrm{OCT})$. The cyclodialysis cleft (CC) was monitored with the help of a single-mirror goniolens, B-scanning and UBM (Marvel B-scan with UBM, Appasamy medical equipment (P) Itd; India) with the sensor operating at $50 \mathrm{MHz}$ and $30 \mathrm{MHz}$ and up to $30 \mathrm{~dB}$, and OCT (Visante OCT, Zeiss; Germany).

The patients were examined on 1st day, 1 week, 1, 3 and 6 months and 1 year after surgery. Each examination included gonioscopy, tonometry, visual acuity testing. The anterior chamber angle (ACA), CC condition and position of the implant were registered with the AIA 11 slit lamp (Appasamy associates, India) and its built-in Canon digital camera (Canon; China).

The main efficacy criteria were IOP dynamics, number of hypotensive drugs used, number of intra- and postoperative complications, and need for a repeat surgery. Descriptive statistical methods were applied to analyze the results of the study: mean, 95\% confidence interval $(\mathrm{Cl})$ and standard deviation were calculated; Student's test was used to determine the significance $(P)$. Statistical processing of the digital data was performed with the help of SPSS Statistics (IBM) 22.0 (USA) for Windows 10.

Nesterov-Vurgaft-Kiselev-Tanyashina's table [14] was used to convert tonometry IOP data into true IOP $\left(\mathrm{P}^{\circ}\right)$.

Surgical outcomes were evaluated as per World Glaucoma Association recommendations [15]. It was considered a complete success if $\mathrm{P}^{\circ}$ was $\leq 15$ for moderate glaucoma patients and $\leq 12 \mathrm{mmHg}$ for severe glaucoma patients or when the IOP decrease was by more than $30 \%$ against baseline, and $\mathrm{P}^{\circ}$ was $>6 \mathrm{mmHg}$.

Further, a complete success was registered when the target pressure was achieved without hypotensive medication; in case additional hypotensive medications were required to achieve the target IOP, the success was considered as partial. Criteria for a failure were inability to achieve the target pressure even with additional hypotensive medications and the need for a repeat surgical intervention.

\section{Surgery technique}

The surgical field was prepared with $0.5 \%$ chlorhexidine (ethanol) solution and 5\% aqueous povidone-iodine solution (Betadine, EGIS; Hungary), followed by instillation of local anesthetic (proxymethacaine $0.5 \%$ solution, Alcaine) (Alcon; USA) in conjunctival sac. A fixation suture was placed at 6 o'clock at the limbus (7-0 polypropylene). Two paracenteses were made at $7-8$ hours or $4-5$ hours. The AC was irrigated with $0.2 \mathrm{ml}$ of $0.01 \%$ carbachol solution to constrict pupil followed by irrigation with $1.4 \%$ hyaluronic acid to maintain $A C$ depth during surgery and, to avoid post-operative hypotony and hyphema. A conjunctivotomy was performed parallel to the limbus running from 10 to 13 hours. A $5 \mathrm{~mm}$ long conjunctival flap was dissected. Minimal diathermocoagulation of the superficial scleral vessels was performed when needed. Five mm away from the limbus, a $1 / 2$ thickness rectangular scleral flap measuring $3 \times 2 \mathrm{~mm}$, was dissected with its base to the limbus (Fig. 1A). In the next step, $4.0 \mathrm{~mm}$ away from the posterior 
border of the surgical limbus and parallel to it an incision up to the ciliary body was made through remaining deep layers of sclera. (Fig. 1B). At the extreme points of this incision, 2 vertical cuts ( $1 \mathrm{~mm}$ long) were made towards limbus on either side to create a valve. (Fig. 1C). A spatula was inserted through paracentesis into the $\mathrm{AC}$ and cyclodialysis ab interno under visual control was performed till its distal end appeared in the incision (Fig. 1D). The spatula was withdrawn and cyclodialysis was completed ab externo through the scleral incision (Fig. 1E). The thus created cyclodialysis tunnel (CT) was filled with 0.1-0.2 ml of cohesive viscoelastic (1.4\% hyaluronic acid). Through the scleral incision an angled long suture tying forceps with closed tying platforms was inserted through the tunnel until its ends were visible in the anterior chamber angle. At this stage the arms of the forceps were released to widen the cleft as wide as the incision in the sclera (Fig. 1F). Cyclodialysis was further advanced under the back lip of the incision in the sclera to expand it towards the suprachoroidal space. Next, using the same angled forceps the $\mathrm{NACl}$ (pre-moistened in a balanced salt solution) was captured between the tying platforms in such a way that distal $0.5 \mathrm{~mm}$ of tying platforms remained free (Fig. 1G). Under visual control, the forceps with $\mathrm{NACl}$ was inserted through the incision in the sclera and pushed forward until the distal ends of the forceps and the $\mathrm{NACl}$ appeared in the AC's angle. After this, the forceps was opened and withdrawn carefully leaving the implant in the tunnel. The posterior end of the implant was inserted under the back lip of the incision into the suprachoroidal space (Fig. 1H). The NACl's position in the tunnel was checked (Fig. 1I). Once satisfied, the superficial scleral flap was put back in its place and sutured with 2 interrupted sutures (10-0 nylon). Conjunctiva was sutured to the limbus using the same suture material. The corneal incisions were sealed with corneal stromal hydration. At the end of the operation, $0.2 \mathrm{ml}$ of dexamethasone solution was injected under the conjunctiva. Antibacterial ointment in the conjunctival cavity and a sterile aseptic dressing were applied to the eye. Conjunctival sutures were removed on 7th day after surgery.

Thus, the technique allowed to create a CT of sufficient width to enable reliable communication between $A C$ and the supraciliary space that, in turn, communicates with the suprachoroidal space, which is the key to the aqueous humor outflow via UP.

The Xenoplast implants used in this study were customized as per needs. Its dimensions were changed to $6.0 \times 1.0 \times 0.5 \mathrm{~mm}$ instead of the standard $4.0 \times 1.0 \times 0.5 \mathrm{~mm}$. This length was necessary to have the implant reaching the suprachoroidal space with $1 \mathrm{~mm}$ being left behind in the $\mathrm{AC}$ angle.

\section{RESULTS}

The mean baseline IOP was $29.5 \pm 6.8 \mathrm{mmHg}$. $(95 \% \mathrm{Cl}$ 26.6-32.3). Twelve months after surgery, the mean IOP was $18.8 \pm 4.3 \mathrm{mmHg}$. (95\% Cl 16.9-20.6; $p \leq 0.01)$. The decrease in IOP was by $33.8 \pm 18.8 \%$ against the baseline. Figure 2 shows the IOP dynamics at different follow-up visits.

A significant decrease in IOP was registered in postoperative period. As compared to baseline IOP, at 1, 3, 6 and 12 months after surgery the decrease was by $37.6 \pm 16.4 \%$, $33.6 \pm 10.7 \%$, $32.1 \pm 13.0 \%$ and $33.8 \pm 18.8 \%$, respectively.

The mean number of hypotensive medications used before the surgery was $2.8 \pm 0.9(95 \% \mathrm{Cl} 2.5-3.2)$. Twelve months after surgery this reduced to $0.6 \pm 0.9(95 \% \mathrm{Cl} 0.2-0.9)$ $(p \leq 0.01)$, a reduction by more than $80 \%$. Figure 3 shows use of hypotensive medications at different follow-up visits.

Complete success was registered in $84.6 \%$ of cases (22 patients) at 1 and 3 months after surgery, in $80.8 \%$ of cases (21 patients) - at 6 months and in $73.1 \%$ of cases (19 patients) - at 12 months. Partial success was in $15.4 \%$ (4 patients), $15.4 \%$ (4 patients), $19.2 \%$ (5 patients) and $26.9 \%$ (7 patients) of cases at 1, 3, 6 and 12 months, respectively. There were no failures
A

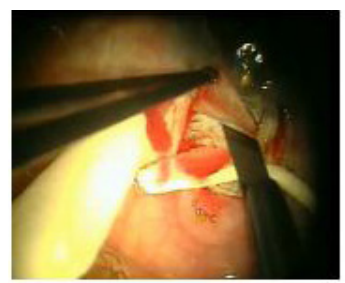

D

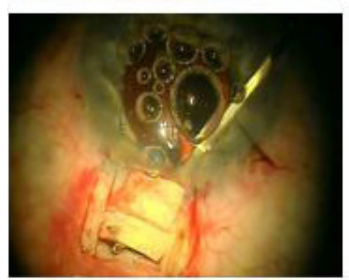

G

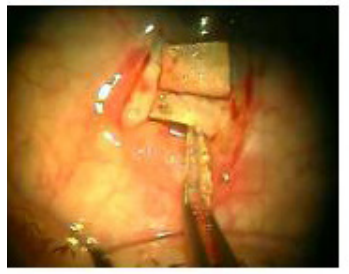

B

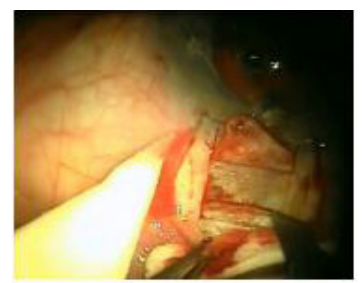

E

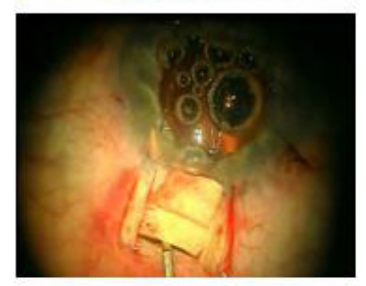

$\mathrm{H}$

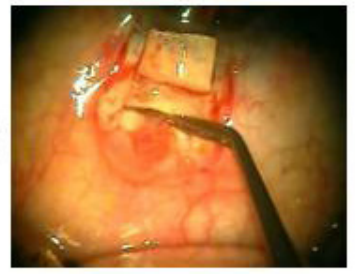

C

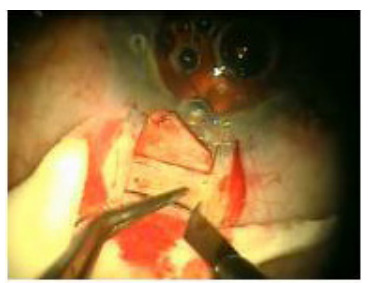

F

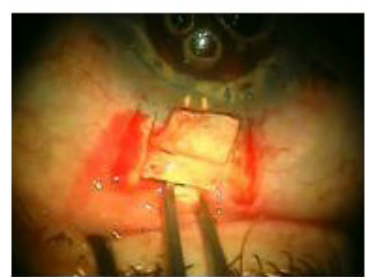

I

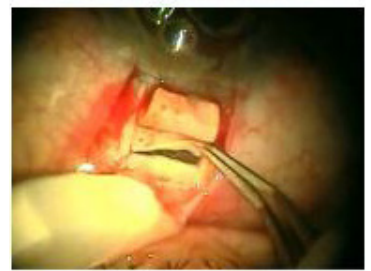

Fig. 1. A. Dissection of limbal based superficial scleral flap $(3 \times 2 \mathrm{~mm})$. B. Horizontal incision of the sclera's deep layers up to the ciliary body. C. Formation of the valve by making 2 vertical incisions $1.0 \mathrm{~mm}$ long at both ends of the incision. D. Cyclodialysis ab interno step. Using a spatula inserted into AC through the paracentesis the ciliary body was separated from the scleral spur, spatula's distal end exiting through the incision in the sclera. E. Completion of tunnel formation ab externo. The spatula was inserted through the scleral incision, its end entered the AC; the ciliary body was detached from sclera along the entire length of the incision. F. CT expansion with the help of suture tying forceps. G. NACI implantation into the supraciliary space. Pre-moistened in the balanced salt solution NACI was captured between tying platforms of the forceps and was inserted into the tunnel through the incision in the sclera and was pushed forward till it appeared in the AC angle. $\mathrm{H}$. NACl implantation in the suprachoroidal space. Posterior end of the implant was captured with toothed forceps and inserted under the back lip of the scleral incision into the suprachoroidal space. I. NACI position checkup 


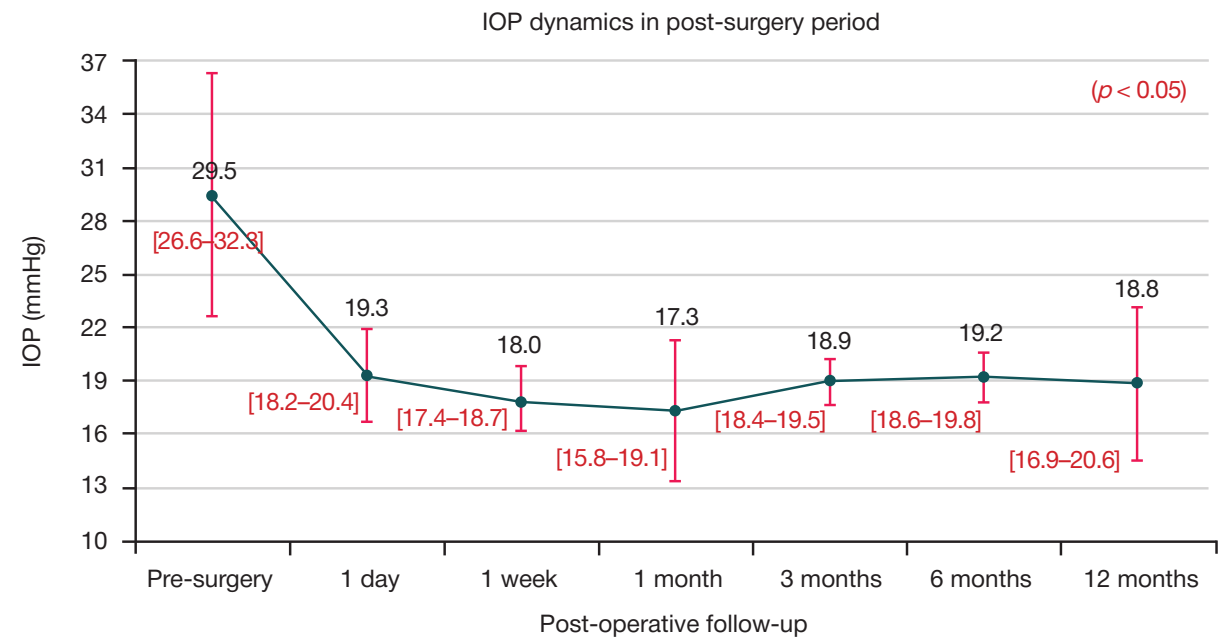

Fig. 2. Graph showing IOP dynamics after cyclodialysis ab externo with implantation of $\mathrm{NACl}$ at different follow-up visits

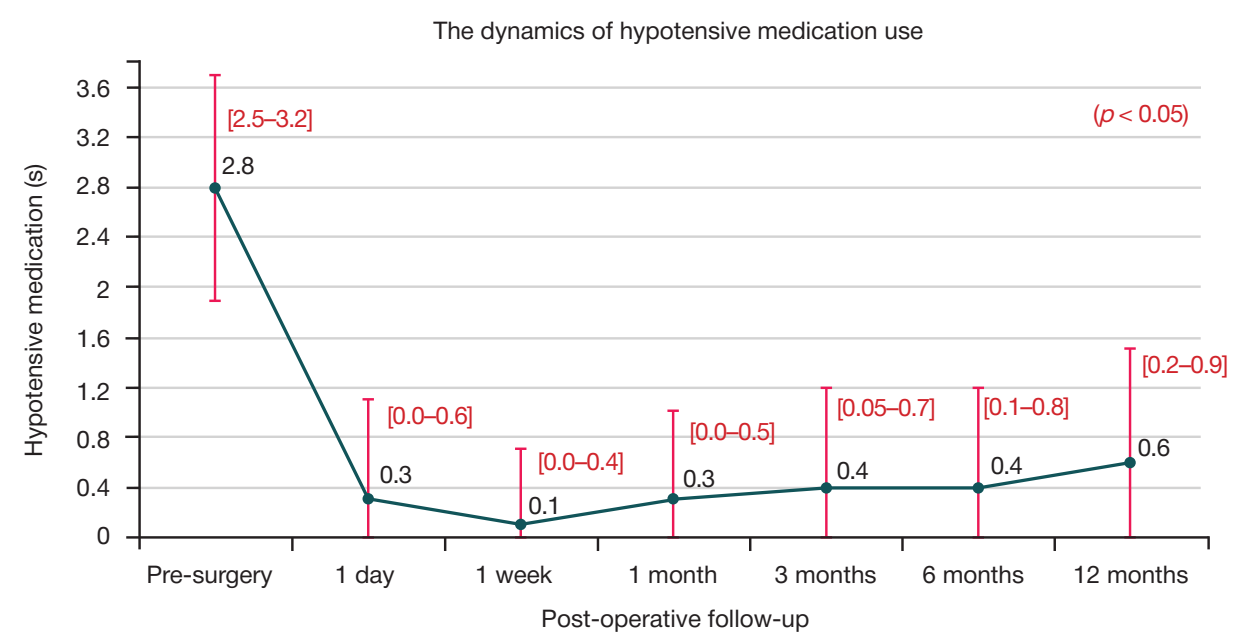

Fig. 3. Use of hypotensive medication by POAG patients at different follow-up visits

registered in this clinical study: up to 1 year after the surgery all the participating patients had their IOP normalized.

In patients with partial success hypotensive drugs were prescribed (1\% and $2 \%$ pilocarpine, $0.5 \%$ timolol, $0.005 \%$ latanoprost, $2 \%$ dorzolamide and their combinations), which brought the IOP down to the target values and below.

In most of the cases, during surgery there was intraoperative mild hemorrhage in the area of cyclodialysis. To prevent further possible complications, the AC was irrigated with balanced salt solution before hydrating the corneal incisions.

\section{Post-operative follow-up}

Early postoperative period. Filtration bleb. A flat bleb was registered in 7 (27\%) patients on the first day after surgery, in $4(15 \%)$ patients it developed during the 1 st week. In 1 patient (4\%) the bleb lasted for a period of 1 month. After 3 months there were no filtering blebs noticed in any of the patients.

Hyphema. Through the entire follow-up period there was only one case of hyphema. Its level measured less than $1 \mathrm{~mm}$; it self-resorbed within 3-5 days without any additional medication. There were another 2 cases with some blood elements in aqueous humour. In both cases it resolved without interventions.

Hypotension and shallow AC. $\mathrm{P}^{\circ}$ below $6 \mathrm{mmHg}$ was considered hypotension; this value corresponds to $14.5 \mathrm{mmHg}$ IOP value measured with a tonometer following the Maklakov method with a weight of $10.0 \mathrm{~g}$. The minimum IOP value registered after surgery was $15 \mathrm{mmHg}$, i.e. there were no cases of hypotension. One patient had shallow AC; in this case, a combined surgery was performed for a concomitant pathology. An iris-claw intraocular lens (Appasamy associates, India) was implanted in the retro pupillary space. The patient had a pupillary block that needed laser iridectomy. After iridectomy the block was resolved, and AC deepened.

There were no complications registered in the late postoperative period. Gonioscopically, $\mathrm{NACl}$ was stable and maintained its position in CT, no shift or total dislocation was observed (Fig. 4). Also, there were no obvious signs of inflammation observed.

Imaging of the formed outflow paths. To assess state of the created CT and position of the implant in the tunnel ultrasound B-scanning and UBM of the surgery zone, as well as longitudinal and transverse OCT of the anterior segment of the eye, were done (Fig. 5), (Fig. 6). Integrity of the CT at 12 months post-operatively was confirmed. The $\mathrm{NACl}$ was in the supraciliary and suprachoroidal spaces, which were expanded.

\section{DISCUSSION}

Today, there are many surgical techniques aimed at activating aqueous humor outflow through natural paths $[6-9,11,13]$. The most interesting of them imply activation of the UOP $[6,9,11,13]$. The majority of UOP activation surgeries include elements of cyclodialysis [16-18]. Some Russian 
A

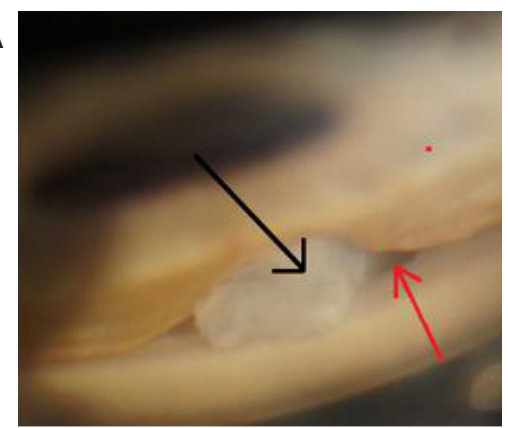

B

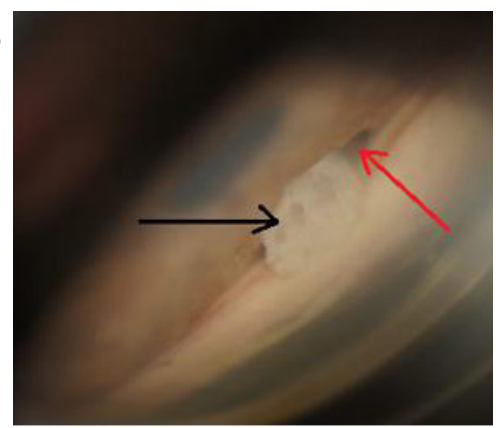

Fig. 4. Gonioscopy view of the AC angle. A. 1 month after surgery. B. 12 months after surgery. NACl (black arrow) is in the CT; CC is clearly visible (red arrow)

A

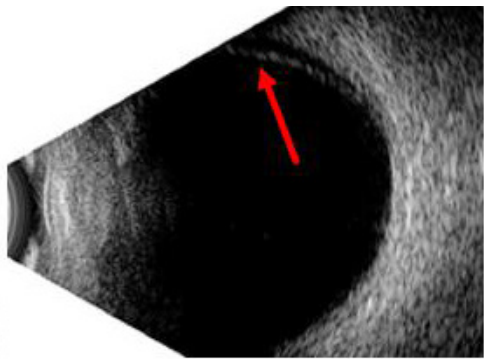

B

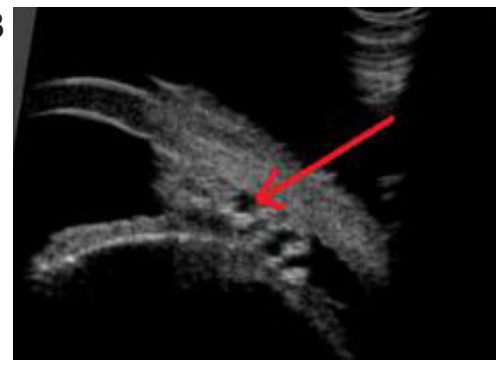

Fig. 5. Ultrasound examination of the surgical area. Post-operative follow-up - 12 months. A. Ultrasonic B-scan. The cyclodialysis tunnel is clearly visible. B. Ultrasonic biomicroscopy. The $\mathrm{NACl}$ is in the created tunnel. No dislocation was observed. Implants porous structure is clearly visible

A

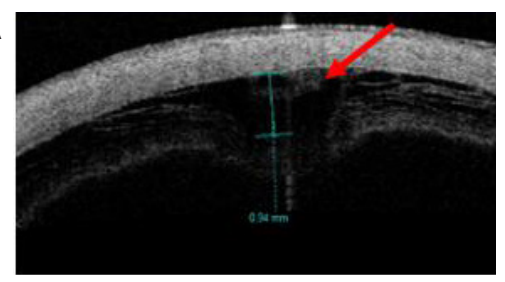

B

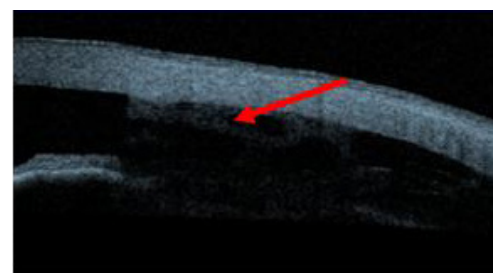

Fig. 6. OCT of the anterior segment of the eye. Post-operative follow-up -12 months. A. Transverse section. B. Iongitudinal section. The NACl in the supraciliary and suprachoroidal spaces is clearly visible. The spaces are expanded

ophthalmologists suggested using autologous sclera as drainage device in the context of the UOP outflow surgery [19].

Two-year observation of 55 refractory glaucoma patients that underwent cyclodialysis ab externo and had Gold Shunt drainage device implanted revealed that the IOP level stabilized in $67.3 \%$ of cases aided by additional hypotensive medication. Only 3 patients (5.5\%) did not need supplementary therapy to have the IOP level reach the target values. The registered postsurgery complications were ciliochoroidal detachment, corneal edema, and excessive filtering. The main factor that makes Gold Shunt implants inefficient is formation of a thin fibrous membrane that obliterates the front end of the drainage device [20].

There is a report [21] that states Gold Shunt inefficiency in patients with advanced stages of glaucoma: $77 \%$ of cases required repeat hypotensive surgery due to high IOP. Examination of the 5 explanted Gold Shunt implants revealed that the reason of their failure is the fibrous tissue that prevented aqueous humor outflow through the $\mathrm{CC}$ and the implant's slits [22].

In case of well-known CyPass Micro-Stent, which was implanted in the supraciliary space ab interno while treating a concomitant pathology secured, only a 14\% reduction of IOP at 12 months post-surgery [23]. The surgery lead to complications, such as temporary hypotension, transient IOP increase and microshunt slit obstruction. Other researchers also reported CyPass Micro-Stent slit obstruction and CC obliteration as the main cause of IOP decompensation [24]. Some ophthalmic surgeons used a YAG laser to reopen the drainage; the procedure allowed restoring of fluid outflow through the microshunt and normalizing IOP [25]. Recently,
Alcon discontinued its CyPass microshunt due to significant loss of endothelial cells 5 years after implantation.

To date, there are few studies investigating Aquashunt and iStent Supra systems in the context of glaucoma surgery [11, 26]. It should be noted that Aquashunt is implanted into the CC ab externo, and iStent Supra - ab interno.

There are also reports describing the effect of phacoemulsification on IOP in the early and late postoperative periods in patients with POAC $[27,28]$. Some authors noted a $3-3.5 \mathrm{mmHg}$ increase in IOP in the early post-operative period (up to 2 weeks). By the end of the first month after surgery the IOP level returned to its pre-surgery values. At 3 months authors noted a mean decrease in IOP by $3.1 \mathrm{mmHg}$ from the baseline [27]. Another study reported a decrease in IOP level by $1.7 \pm 3.1 \mathrm{mmHg}$ from the baseline at 12 months after surgery [28]. In our study, 18 (69.2\%) patients presented concomitant pathologies that were treated simultaneously with the main disease. The IOP level decreased by $11 \pm 7.3 \mathrm{mmHg}$ from the baseline at 12 months after surgery. The significant IOP decrease at 12 months after surgery proves more marked hypotensive effect by our technique than by phacoemulsification alone.

In this study cyclodialysis ab externo with implantation of $\mathrm{NACl}$ has been advocated for severe glaucoma patients. The surgery aims to activate outflow through UOP by forming a CT connecting $\mathrm{AC}$ to the supraciliary and suprachoroidal spaces. Implantation of the NACl in the CT ensures lasting and effective opening of the tunnel, thus activating aqueous outflow through UOP and secures persistence of the hypotensive effect. Watertight closure of scleral incisions helps avoiding filtration under the conjunctiva, which is unnatural. The surgery is 
minimally traumatic. Sclera was sectioned between two rectus muscles so that the eyeball's mobility remained undisturbed. Cyclodialysis ab interno was necessary to avoid any descemet's membrane detachment, while detaching the ciliary body from the scleral spur. This is a common complication occurred if the approach is ab externo. In our ab interno - ab externo combined approach, a limited amount of ciliary body is detached from the scleral spur ab interno, thus creating a shallow cleft, which is then enlarged by ab externo approach. The scleral valve facilitates insertion of instruments through the scleral incision into supraciliary space, thus reduces trauma to the ciliary body. The valve is also an eyeball anchor point, which facilitates manipulations in the supraciliary space.

The NACl "Xenoplast" implanted into supraciliary and suprachoroidal spaces was selected because of its high biocompatibility with the eye tissues and lack of a pronounced inflammation after implantation due to the material being nontoxic and non-immunogenic [29]. The implant is available in dry form; when wetted, it swells no more than $0.1 \%$. Its porous structure (pore size 200-700 $\mu \mathrm{m}$ ) allows the fluid flow through the entire structure. A large number of studies implying nonpenetrating deep sclerectomy with $\mathrm{NACl}$ implantation in the intrascleral space demonstrate the high efficiency of this implant The authors reported a persistent decrease of the IOP level 1.5 years after surgery in patients with advanced glaucoma: the IOP reached $13.0 \pm 0.5 \mathrm{mmHg}$ without hypotensive medication [30]

In this series over the entire follow-up period not a single failure case was registered. Obvious signs of inflammation, hypotension, reactive syndrome, $\mathrm{NACl}$ dislocation was not observed, which confirm safety of the suggested surgical technique. There was only one case of hyphema, which resolved within 5 days.

Twelve months after valve cyclodialysis ab externo with $\mathrm{NACl}$ implantation the mean IOP decreased by $33.8 \pm 8.8 \%$ from the baseline and equaled to $18.8 \pm 4.4 \mathrm{mmHg}(p \leq 0.01)$, which proves the high hypotensive efficacy of the suggested modality. Another proof thereof is the $80.1 \%$ reduction in the use of hypotensive medication (from $2.8 \pm 0.9$ to $0.6 \pm 0.9$ ) $(p \leq 0.01)$ at 12 months after surgery, which improves the patients' quality of life and significantly reduces their expenses on medicine purchase. It should be noted that through the follow-up period all cases ended in a overall success: complete success in $73.1 \%$ of cases (19 patients), partial — in $29.9 \%$ of cases (7 patients).

\section{CONCLUSION}

Valve cyclodialysis ab externo with implantation of the Xenoplast $\mathrm{NACl}$ in the supraciliary space proved to be a highly effective and safe way to decrease IOP and the amount of hypotensive medications used in the advanced stage POAG patients; the number of complications associated with the surgery is minimal.

Thus, the suggested valve cyclodialysis ab externo with implantation of Xenoplast $\mathrm{NACl}$ is a highly effective and safe surgery for advanced staged POAG.

\section{References}

1. Egorov EA, Astakhov YuS, Erichev VP. Natsional'noe rukovodstvo po glaukome. M.: GEOTAR-Media, 2015; 457 p.

2. Liebman ES. Present-day positions of the clinical-and-social ophthalmology. Vestnik oftal'mologii. 2004; 120 (1): 10-2.

3. Lovpache JN, Arakelyan MA, Ramazanova KA. Hypotinsive effect, tolerance and safety of the preparations Timolol 0,5\%, Dorzolamide and combination of these preparations in treatment of patients with primary open-angle glaucoma. Ros. oftal'mol. zhurnal. 2011; (1): 40-5.

4. Svetozarskiy SN, Maslennikova YA, Anikeeva MV. Modern Technologies of Open-Angle Glaucoma Surgery. STM. 2014; 6 (1): 102-9.

5. 5-de Moraes CG, Liebmann JM, Medeiros FA, Weinreb RN Management of advanced glaucoma: Characterization and monitoring. Surv Ophthalmol. 2016; 61 (5): 597-615.

6. Kumar V, Frolov MA, Dushina GN, Shradqa AS, Bezzabotnov AI. Reverse meridional cyclodialysis ab interno with implantation of metallic implant in patientswith glaucoma of different etiology. Vestnik oftal'mologii. 2019; 135 (3): 10-9.

7. Johnson M, Mclaren JW, Overby DR. Unconventional aqueous humor outflow: A review. Exp Eye Res. 2017; (158): 94-111.

8. Carreon $T$, van der Merwe E, Fellman RL, Johnstone $M$, Bhattacharya SK. Aqueous outflow - A continuum from trabecular meshwork to episcleral veins. Prog Retin Eye Res. 2017; (57): 108-33.

9. Frolov MA, Frolov AM, Kazakova KA. Combination treatment for cataract and glaucoma. Vestnik oftal'mologii. 2017; 133 (4): 42-6.

10. Yucel Y, Gupta N. Lymphatic drainage from the eye: A new target for therapy. Prog Brain Res. 2015; (220):185-98.

11. Kammer JA, Mundy KM. Suprachoroidal Devices in Glaucoma Surgery. Middle East Afr Ophthalmol. 2015; 22 (1): 45-52.

12. Tanito M, Chihara E. safety and effectiveness of gold glaucoma micro shunt for reducing intraocular pressure in Japanese patients with open angle glaucoma. Jpn J Ophthalmol. 2017; 61 (5): 388-94.
13. Grisanti S, Grisanti S, Garcia-Feijoo J, Dick HB, Munoz-Negrete FJ, Arrondo E., et al. Supraciliary microstent implantation for openangle glaucoma: multicentre 3-year outcomes. BMJ Open Ophthalmol. 2018; 22 (1): e000183.

14. Krasnov MM. Mikrokhirurgiya glaukom, 2-eizdanie. M.: Meditsina, 1980; 248 c.

15. Shaarawy TM, Grehn F, Sherwood MB, editors. Guidelines on design and reporting of glaucoma surgical trials. World Glaucoma Association. Amsterdam: Kugler publications, 2008; 2009.

16. Kolesnikova LH, Pantsireva LP, Svirin AB. Dilation of suprachoroidal space in combination with cyclodialysis. Vestnik oftal'mologii. 1976; (4): 18-20.

17. Demeler U. Direct cyclopexy following operative and traumatic cyclodialysis. Fortschr Ophthalmol. 1984; (81): 466-8.

18. Kumar V, Frolov MA, Dushina GN, Shradqa AS, Bezzabotnov Al. Reverse meridional cyclodialysis ab interno in surgical management of different types of glaucoma: Long-term results. Natsional'nyy zhurnal glaukoma. 2018; 17 (4): 63-73.

19. Frolov MA, Ryabey AV, Frolov AM, Al' Khatib NS. Rezul'taty modifitsirovannoy sinustrabekulektomii s bazal'noy iridektomiey, drenirovaniem peredney kamery i suprakhorioidal'nogo prostranstva autoskleroy pri pervichnoy otkrytougol'noy glaukome. Tochka zreniya. Vostok — zapad, nauchno-prakticheskiy zhurnal. 2018; (3): 23-6.

20. Figus M, Lazzeri S, Fogagnolo P, Laster M, Martinelli P, Nardi M. Supraciliary shunt in refractory glaucoma. Br J Ophthalmol. 2011; 95 (11): 1537-41.

21. Hueber A, Roters S, Jordan JF, Konen W. Retrospective analysis of the success and safety of Gold Micro Shunt Implantation in glaucoma. BMC Ophthalmol. 2013; (13): 35.

22. Agnifili L, Costagliola C, Figus M, Lezzi G, Piattelli A, Carpineto, et al. Histological findings of failed gold micro shunts in primary open-angle glaucoma. Graefes Arch Clin Exp Ophthalmol. 2012; 250 (1): 143-9.

23. Hoeh H, Vold SD, Ahmed IK, Anton A, Rau M, Singh K, et al. 
Initial Clinical Experience with the CyPass Micro-Stent: Safety and Surgical Outcomes of a Novel Supraciliary Microstent. J Glaucoma. 2016; 25 (1): 106-12.

24. Grisanti S, Margolina E, Hoeh H, Rau M, Erb C, Kersten-Gomez, et al. Supraciliary microstent for open-angle glaucoma: clinical results of a prospective multicenter study. Ophthalmologe. 2014; 111 (6): 548-52.

25. Perez $\mathrm{Cl}$, Chansangpetch S, Hsia YC, Lin SC. Use of Nd:YAG laser to recanalize occluded Cypass Micro-Stent in the early postoperative period. Am J Ophthalmol Case Rep. 2018; (10): 114-6.

26. Gigon A, Shaarawy T. The Suprachoroidal Route in Glaucoma Surgery. J Curr Glaucoma Pract. 2016; 10 (1): 13-20.

27. Rjabceva AA, Jugaj MP. Izmenenie vnutriglaznogo davlenija $\vee$ rannie sroki posle fakojemul'sifikacii katarakty. Tochka zrenija. Vostok — zapad, nauchno-prakticheskij zhurnal. 2014; (1): 84.

28. DeVience E., Chaudhry S., Saeedi OJ. Effect of intraoperative factors on IOP reduction after phacoemulsification. Int Ophthalmol. 2017; 37 (1): 63-70.

29. Anisimov SI, Anisimova SYu, Drozdova GA, Larionov EV, Rogacheva IV. Patofiziologicheskie aspekty ispol'zovaniya novogo biologicheskogo materiala ksenoplast $v$ khirurgicheskom lechenii glaukomy. Natsional'nyy zhurnal glaukoma. 2008; (2): 40-5.

30. Anisimova SYu, Anisimov SI, Rogacheva IV. khirurgicheskoe lechenie rafrakternoy glaukomy $s$ ispol'zovaniem novogo, stoykogo k biodestruktsii kollagenovogo drenazha. Natsional'nyy zhurnal glaukoma. 2006; (2): 51-6.

\section{Литература}

1. Егоров Е. А., Астахов Ю. С., Еричев В. П. Национальное руководство по глаукоме. М.: ГЭОТАР-Медиа, 2015; 457 с.

2. Либман Е. С. Современные позиции клинико-социальной офтальмологии. Вестник офттальмологии. 2004; 120 (1): 10-2.

3. Ловпаче Дж. Н., Аракелян М. А., Рамазанова К. А. Гипотензивная эффективность, переносимость и безопасность препаратов Тимолол 0,5\%, Дорзопт 2\%, комбинации Тимолол 0,5\% и Дорзопт 2\% в лечении пациентов с первичной открьпоугольной глаукомой. Рос. офттальмол. журнал. 2011; (1): 40-5.

4. Светозарский С. Н., Масленникова Ю. А., Аникеева М. В. Современные технологии хирургического лечения открытоугольной глаукомы. СТМ. 2014; 6 (1): 102-9.

5. de Moraes CG, Liebmann JM, Medeiros FA, Weinreb RN. Management of advanced glaucoma: Characterization and monitoring. Surv Ophthalmol. 2016; 61 (5): 597-615.

6. Кумар В., Фролов М. А., Душина Г. Н., Шрадка А. С., Беззаботнов А. И. Обратный меридиональный циклодиализ ab interno c введением в супрацилиарное пространство металлического имплантата при глаукоме различной этиологии. Вестник офтальмологии. 2019; 135 (3): 10-9.

7. Johnson M, Mclaren JW, Overby DR. Unconventional aqueous humor outflow: A review. Exp Eye Res. 2017; (158): 94-111.

8. Carreon $T$, van der Merwe E, Fellman RL, Johnstone $M$, Bhattacharya SK. Aqueous outflow - A continuum from trabecular meshwork to episcleral veins. Prog Retin Eye Res. 2017; (57): 108-33.

9. Фролов М. А., Фролов А. М., Казакова К. А. Комбинированные методы лечения при сочетании катаракты и глаукомы. Вестник офтальмологии. 2017; 133 (4): 42-6.

10. Yucel Y, Gupta N. Lymphatic drainage from the eye: A new target for therapy. Prog Brain Res. 2015; 220: 185-98.

11. Kammer JA, Mundy KM. Suprachoroidal Devices in Glaucoma Surgery. Middle East Afr Ophthalmol. 2015; 22 (1): 45-52.

12. Tanito M, Chihara E. safety and effectiveness of gold glaucoma micro shunt for reducing intraocular pressure in Japanese patients with open angle glaucoma. Jpn J Ophthalmol. 2017; 61 (5): 388-94.

13. Grisanti S, Grisanti S, Garcia-Feijoo J, Dick HB, Munoz-Negrete FJ, Arrondo E, et al. Supraciliary microstent implantation for openangle glaucoma: multicentre 3-year outcomes. BMJ Open Ophthalmol. 2018; 22 (1): e000183.

14. Краснов М. М. Микрохирургия глауком, 2-е издание. М.: Медицина; 1980; 248 с.

15. Shaarawy TM, Grehn F, Sherwood MB, editors. Guidelines on design and reporting of glaucoma surgical trials. World Glaucoma Association. Amsterdam: Kugler publications, 2008; 2009.

16. Колесникова Л. Н., Панцырева Л. П., Свирин А. В. Дилятация супрахориоидального пространства в комбинации с циклодиализом. Вестник офтальмологии. 1976; 4: 18-20.

17. Demeler U. Direct cyclopexy following operative and traumatic cyclodialysis. Fortschr Ophthalmol. 1984; 81: 466-8.
18. Кумар В., Фролов М. А., Душина Г. Н., Шрадка А. С., Беззаботнов А. И. Обратный меридиональный циклодиализ ab interno в хирургическом лечении глаукомы различной этиологии: отдаленные результаты. Национальный журнал глаукома. 2018; 17 (4): 63-73.

19. Фролов М. А., Рябей А. В., Фролов А. М., Аль Хатиб Н. С. Результаты модифицированной синустрабекулэктомии с базальной иридэктомией, дренированием передней камеры и супрахориоидального пространства аутосклерой при первичной открытоугольной глаукоме. Точка зрения. Восток - запад, научно-практический журнал. 2018; (3): 23-6.

20. Figus M, Lazzeri S, Fogagnolo P, Laster M, Martinelli P, Nardi M. Supraciliary shunt in refractory glaucoma. Br J Ophthalmol. 2011; 95 (11): 1537-41.

21. Hueber A, Roters S, Jordan JF, Konen W. Retrospective analysis of the success and safety of Gold Micro Shunt Implantation in glaucoma. BMC Ophthalmol. 2013; (13): 35.

22. Agnifili L, Costagliola C, Figus M, Lezzi G, Piattelli A, Carpineto, et al. Histological findings of failed gold micro shunts in primary open-angle glaucoma. Graefes Arch Clin Exp Ophthalmol. 2012; 250 (1): 143-9.

23. Hoeh H, Vold SD, Ahmed IK, Anton A, Rau M, Singh K, et al. Initial Clinical Experience with the CyPass Micro-Stent: Safety and Surgical Outcomes of a Novel Supraciliary Microstent. J Glaucoma. 2016; 25 (1): 106-12.

24. Grisanti S, Margolina E, Hoeh H, Rau M, Erb C, Kersten-Gomez, et al. Supraciliary microstent for open-angle glaucoma: clinical results of a prospective multicenter study. Ophthalmologe. 2014; 111 (6): 548-52.

25. Perez Cl, Chansangpetch S, Hsia YC, Lin SC. Use of Nd: YAG laser to recanalize occluded Cypass Micro-Stent in the early postoperative period. Am J Ophthalmol Case Rep. 2018; (10): 114-6.

26. Gigon A, Shaarawy T. The Suprachoroidal Route in Glaucoma Surgery. J Curr Glaucoma Pract. 2016; 10 (1): 13-20.

27. Рябцева А. А., Югай М. П. Изменение внутриглазного давления в ранние сроки после факоэмульсификации катаракты. Точка зрения. Восток - запад, научно-практический журнал. 2014; (1): 84

28. DeVience E, Chaudhry S, Saeedi OJ. Effect of intraoperative factors on IOP reduction after phacoemulsification. Int Ophthalmol. 2017; 37 (1): 63-70.

29. Анисимов С. И., Анисимова С. Ю., Дроздова Г. А., Ларионов Е. В., Рогачева И. В. Патофизиологические аспекты использования нового биологического материала ксенопласт в хирургическом лечении глаукомы. Национальный журнал глаукома. 2008; (2): 40-5.

30. Анисимова С. Ю., Анисимов С. И., Рогачева И. В. хирургическое лечение рафрактерной глаукомы с использованием нового, стойкого к биодеструкции коллагенового дренажа. Национальный журнал глаукома. 2006; (2): 51-6. 